\title{
AKTIVITAS ANTIOKSIDAN PERASAN JERUK MANIS (CitruS sinensis) DAN JERUK PURUT (Citrus hystrix) MENGGUNAKAN METODE ABTS
}

\author{
Anita Dwi Puspitasari, Sumantri \\ Departemen Kimia Farmasi, Fakultas Farmasi, Universitas Wahid Hasyim, Semarang
}

Kata Kunci :

Citrus sinensis, Citrus hystrix, Antioksidan, ABTS

\begin{abstract}
ABSTRAK
Tubuh membutuhkan antioksidan untuk menangkal bahaya radikal bebas yang berpengaruh terhadap kesehatan. Antioksidan dapat mencegah terjadinya berbagai penyakit degenaratif dan penyakit lainnya. Buah jeruk manis (Citrus sinensis) dan Buah jeruk purut (Citrus hystrix) mengandung senyawa flavonoid dan vitamin $C$ sehingga berpotensi sebagai antioksidan. Penelitian ini bertujuan untuk mengetahui aktivitas antioksidan perasan jeruk manis dan jeruk purut dengan metode ABTS (2,2-Azinobis(3ethylbenzothiazoline)-6-sulfonic acid). Buah jeruk manis dan jeruk purut dicuci bersih dan diperas sehingga dihasilkan perasan jeruk manis dan jeruk purut. Perasan jeruk manis dan jeruk purut diidentifikasi kandungan senyawa flavonoidnya dengan serbuk magnesium dan $\mathrm{HCl}$ pekat sebagai pereaksi dan kandungan vitamin Cnya dengan pereaksi benedict. Pengukuran aktivitas antioksidan pada perasan jeruk manis dan jeruk purut dengan metode ABTS dilakukan menggunakan spektrofotometer visibel pada panjang gelombang maksimum $753,2 \mathrm{~nm}$, operating time 30 menit dan vitamin C sebagai kontrol positif.Hasil identifikasi kualitatif menunjukkan bahwa perasan jeruk manis dan jeruk purut mengandung senyawa flavonoid dan vitamin $\mathrm{C}$ yang keduanya ditandai dengan perubahan warna dari kuning menjadi jingga. Perasan jeruk manis memiliki aktivitas antioksidan dengan nilai IC50 sebesar $71,34 \pm 0,69$ ppm, jeruk purut sebesar $67,92 \pm 1,75$ ppm dan vitamin $C$ sebesar $7,25 \pm 0,02$ ppm. Perasan jeruk manis dan jeruk purut termasuk antioksidan kuat jika dibandingkan dengan vitamin $\mathrm{C}$.
\end{abstract}

\section{PENDAHULUAN}

Bagian Dewasa ini penyakit degeneratif banyak terjadi di masyarakat yang diakibatkan oleh radikal bebas, seperti misalnya penuaan dini, penyakit Kardiovaskuler, Hipertensi, dan Diabetes (1). Radikal bebas dapat diikat dengan antioksidan sehingga dapat menyembuhkan berbagai penyakit. Antioksidan merupakan suatu senyawa yang dapat menangkal efek negatif radikal bebas dalam tubuh dengan memberikan suatu elektronnya kepada senyawa radikal bebas seperti flavonoid, vitamin C, tanin, fenol, terpenoid, dan steroid (2).

Sumber antioksidan dapat berupa antioksidan sintetik maupun alami. Antioksidan sintetik misalnya BHA (buthylated hydroxy anisole), BHT (butylated hydroxy toluene), PG (propyl gallate), dan TBHQ (tertiary butyl hydroquinone) (3). Hasil penelitian menunjukkan bahwa penggunaan antioksidan sintetik dapat menimbulkan penyakit kerusakan hati, kanker, berefek toksik dan karsinogenik pada tubuh manusia (4). Seiring meningkatnya kesadaran orang tentang efek samping yang merugikan maka antioksidan alami lebih banyak dipilih daripada antioksidan sintetik karena dinilai lebih aman. Oleh karena itu perlu pengembangan antioksidan alami yang bersumber dari bahan alam.

Tanaman jeruk manis (Citrus cinensis) dan jeruk purut (Citrus hystrix) merupakan salah satu tanaman obat yang mengandung senyawa antioksidan yang dapat digunakan untuk mencegah dan mengobati berbagai penyakit. Jeruk manis (Citrus sinensis) menunjukkan adanya senyawa kimia yaitu flavonoid, tanin, phenol, terpenoid, vitamin C, dan steroid (5). Sedangkan jeruk purut mengandung flavonoid, vitamin $\mathrm{C}$, steroid dan tanin (6).

Ekstrak etanol jeruk manis memiliki aktivitas antioksidan dengan metode DPPH diperoleh nilai IC 50 sebesar 292,09 $\pm 0,379 \mu \mathrm{g} / \mathrm{mL}$ dan termasuk antioksidan yang lemah (7). Aktivitas antioksidan minyak jeruk purut dengan $\mathrm{IC}_{50} 6,43 \mu \mathrm{g} / \mathrm{ml}$ termasuk antioksidan kuat (8). Buah jeruk manis dan jeruk purut yang digunakan untuk penelitian yaitu perasan, Hal ini mempertimbangkan agar masyarakat lebih mudah dalam penggunaannya.

Pengujian aktivitas antioksidan dalam penelitian ini menggunakan metode ABTS. Metode ABTS memiliki kelebihan dibandingkan dengan metode lain, yaitu pengujian sederhana, mudah diulang, menggunakan alat yang sederhana dan yang paling penting adalah fleksibel dan dapat digunakan untuk mengukur aktivitas antioksidan yang bersifat hidrophilik maupun lipophilik dalam ekstrak makanan dan cairan (9). Metode ABTS memiliki sensitivitas lebih tinggi dibandingkan DPPH, prosesnya cepat, dapat dilakukan pada rentang $\mathrm{pH}$ yang besar serta dapat digunakan pada system larutan berbasis air maupun organik (10).

Dari uraian diatas, maka tujuan dari penelitian ini adalah untuk mengetahui Aktivitas antioksidan perasan jeruk manis (Citrus sinensis) dan jeruk purut (Citrus hystrix) menggunakan metode ABTS. 


\section{METODE PENELITIAN}

\section{Alat dan Bahan}

Alat-alat yang digunakan yaitu Seperangkat alat gelas (Pyrex), alat pemeras jeruk, timbangan elektrik (Ohaus), yellow/blue tip, mikropipet, vortex, pipet tetes, tissue, aluminium foil, sendok tanduk, batang pengaduk, kuvet, spektrofotometer Visibel 1800 (Shimadzu). Bahan uji yang digunakan adalah buah jeruk manis dan jeruk purut. Bahan kimia yang digunakan adalah ABTS (2,2-Azinobis(3ethylbenzothiazoline)-6-sulfonic acid) p.a (Merck), dan kalium persulfat $\left(\mathrm{K}_{2} \mathrm{~S}_{2} \mathrm{O}_{8}\right)$, vitamin $\mathrm{C}$, etanol p.a (Merck), metanol p.a (Merck), aquadest, etanol 70\%, serbuk magnesium, asam klorida, standar rutin (Sigma), pereaksi $\mathrm{AlCl}_{3}$ (Merck), kalium asetat (Merck).

\section{Jalannya Penelitian}

\section{Pengumpulan bahan}

Jeruk manis diambil dari Pati, Jawa Tengah. Dipanen pada umur 8 bulan dari saat bunga mekar, buah jeruk manis yang dipanen berwarna hijau atau kekuning-kuningan, waktu panen diusahakan saat cuaca cerah, cara panen dipetik menggunakan gunting (10). Sedangkan Buah jeruk purut diambil dari Jepara, Jawa Tengah. Buah jeruk purut yang dipanen berwarna hijau atau kekuning-kuningan.

\section{Determinasi tanaman}

Tanaman jeruk manis dan jeruk purut dilakukan determinasi di Laboratorium Ekologi dan Biosistematik Jurusan Biologi, Fakultas Matematika dan Ilmu Pengetahuan Alam, Universitas Diponegoro.

\section{Pembuatan perasan jeruk manis dan jeruk purut}

Sebanyak 350 gram jeruk manis dan jeruk purut dicuci terlebih dahulu dengan air bersih, setelah itu ditiriskan, kemudian dipotong menjadi 2 bagian. Selanjutnya diperas menggunakan alat pemeras jeruk, sehingga diperoleh air perasan jeruk manis dan jeruk purut (11).

\section{Identifikasi senyawa flavonoid}

Tanaman jeruk manis dan jeruk purut dilakukan determinasi di Laboratorium Ekologi dan Biosistematik Jurusan Biologi, Fakultas Matematika dan Ilmu Pengetahuan Alam, Universitas Diponegoro.

\section{Identifikasi Vitamin C}

Sebanyak 5 tetes perasan jeruk manis dan jeruk purut dimasukkan ke dalam tabung reaksi kemudian ditambahkan 15 tetes pereaksi benedict. Tabung reaksi dipanaskan di atas api kecil sampai mendidih selama 2 menit. Perhatikan adanya endapan yang terbentuk. Warna hijau kekuningkuningan sampai merah bata menandakan vitamin $\mathrm{C}$ positif.

\section{Uji Aktivitas Antioksidan Dengan Metode ABTS}

Larutan ABTS (25 mL $7 \mathrm{mM}$ ) direaksikan dengan larutan aquos $\mathrm{K}_{2} \mathrm{~S}_{2} \mathrm{O}_{8}$ (25 mL 2,45 mM) ABTS radikal kation (ABTSẦ $\hat{A}^{+}$. Kemudian larutan tersebut didiamkan di tempat yang gelap selama 6 jam pada suhu ruang, dihasilkan larutan ABTSÂ $^{+}$yang berwarna biru hijau. Sebanyak $50 \mathrm{mg}$ air perasan jeruk manis dan jeruk purut dilarutkan dalam metanol p.a $50 \mathrm{mg}$ hingga diperoleh konsentrasi $1000 \mu \mathrm{g} / \mathrm{mL}$, dari larutan tersebut dibuat seri konsentrasi 5, 10, 20, 40 dan $80 \mu \mathrm{g} / \mathrm{mL}$ direaksikan dengan $1 \mathrm{~mL}$ larutan ABTS $7 \mathrm{mM}$, kemudian divortex selama 30 detik dan didiamkan 10 menit (OT). Absorbansi dibaca pada panjang gelombang 753,2 nm. Vitamin C digunakan sebagai kontrol posiitif.

\section{Perhitungan Nilai IC50}

Aktivitas antioksidan ditunjukkan dengan nilai $\mathrm{IC}_{50}$. Nilai $\mathrm{IC}_{50}$ (50\% Inhibitory Concentration) ditentukan dengan analisis probit dari data log konsentrasi dengan probit persentase pengikatan radikal bebas. Persentase pengikatan radikal bebas dapat dihitung dengan rumus dibawah ini.

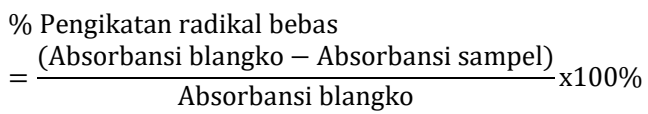

\section{HASIL DAN PEMBAHASAN}

Determinasi terhadap buah jeruk manis dan jeruk purut dilakukan di Laboratorium Ekologi dan Biosistematik Jurusan Biologi, Fakultas Matematika dan Ilmu Pengetahuan Alam, Universitas Diponegoro. Tujuan dari determinasi tanaman adalah untuk memastikan bahwa tanaman yang digunakan dalam penelitian adalah benar-benar tanaman yang diinginkan dan tidak terjadi kesalahan dalam pengumpulan bahan.

Hasil determinasi pada buah jeruk manis menyatakan bahwa buah yang digunakan benar-benar Citrus sinensis dengan kunci determinasi sebagai berikut: 1b, 2b, 3b, 4b, 6b, 7b, 9b, 10b, 11b, 12b, 13b, 14a, 15b, 197a, 208b, 219b, 220a, 221a, 111. Fam. Rutaceae, 1a.Genus: Citrus, Spesies: Citrus sinensis (Jeruk manis), berdasarkan pustaka Flora, untuk Sekolah Indonesia (12).

Hasil determinasi pada buah jeruk purut menyatakan bahwa buah yang digunakan benar-benar Citrus hystrix dengan kunci determinasi sebagai berikut: $1 \mathrm{~b}, 2 \mathrm{~b}, 3 \mathrm{~b}, 4 \mathrm{~b}, 6 \mathrm{~b}, 7 \mathrm{~b}, 9 \mathrm{~b}$, 10b, 11b, 12b, 13b, 14a, 15b, 197a, 208b, 219b, 220a, 221a, 111. Fam. Rutaceae, 1a. Genus: Citrus, Spesies: Citrus hystrix (Jeruk purut), berdasarkan pustaka Flora, untuk Sekolah Indonesia (12).

Dari 350 gram buah jeruk manis dan jeruk purut dihasilkan air perasan jeruk manis sebanyak $90 \mathrm{~mL}$ dan air perasan jeruk purut sebanyak $80 \mathrm{~mL}$. Air perasan jeruk manis yang dihasilkan berwarna kuning dan berasa manis. Sedangkan air perasan jeruk purut yang dihasilkan berwarna kuning dan berasa masam.

Uji flavonoid dilakukan dengan menambahkan pereaksi Mg$\mathrm{HCl}$. Hasil uji identifikasi senyawa flavonoid dari air perasan jeruk manis dan jeruk purut menunjukkan adanya senyawa flavonoid dengan indikasi perubahan warna dari kuning menjadi jingga setelah ditambahkan pereaksi (13). Penambahan logam $\mathrm{Mg}$ dan $\mathrm{HCl}$ pada identifikasi senyawa flavonoid bertujuan untuk mereduksi inti benzopiron yang terdapat dalam struktur flavonoid sehingga terjadi perubahan warna menjadi jingga atau merah ungu yang membentuk garam flavillium (14).

Flavonoid merupakan golongan terbesar senyawa fenol alam. Flavonoid merupakan senyawa polar karena mempunyai sejumlah gugus hidroksil yang tak tersulih atau suatu gula, sehingga akan larut dalam pelarut polar seperti air, etanol, butanol, dan aseton adanya gula yang terikat pada flavonoid cenderung menyebabkan flavonoid lebih mudah larut dalam air, pelarut air merupakan pelarut yang lebih baik untuk glikosida (13).

Uji vitamin $\mathrm{C}$ dilakukan dengan menambahkan pereaksi benedict. Hasil uji identifikasi vitamin $\mathrm{C}$ dari perasan jeruk manis dan jeruk purut menunjukkan adanya vitamin $\mathrm{C}$ dengan indikasi perubahan warna dari kuning menjadi jingga setelah ditambahkan pereaksi (13). 
Penentuan aktivitas antioksidan menggunakan metode ABTS yang merupakan radikal sintetik berwarna biru-hijau. Metode ABTS dapat digunakan untuk mengetahui konsentrasi antioksidan yang mampu menghambat radikal bebas sebanyak 50\% (IC50). Larutan ABTS yang telah dibuat harus tetap dijaga pada suhu rendah, dan terlindung dari cahaya. Hal ini dikarenakan ABTS mempunyai sensitifitas yang cukup tinggi terhadap suhu dan cahaya. ABTS akan memperoleh elektron dari antioksidan sehingga mengalami perubahan warna biru-hijau menjadi bening. Tingkat perubahan warna sebanding dengan konsentrasi antioksidan. Titik akhir reaksi dicapai ketika perubahan warna sudah tidak ada lagi (15)

Data yang dihasilkan dalam menentukan aktivitas antioksidan berupa absorbansi pada Operating Time 10 menit dan Panjang gelombang maksimum 753,2 nm. Penentuan Operating Time (OT) perlu dilakukan untuk mendapatkan waktu dimana reaksi sampel dan pereaksi berada pada kondisi optimum. Absorbansi tersebut didapat saat pengukuran pada panjang gelombang maksimum $1 \mathrm{~mL}$ larutan ABTS $7 \mathrm{mM}$. Reaksi dianggap optimal apabila absorbansi dari tiap selang waktu yang diukur telah stabil. Absorbansi yang stabil terlihat dari makin kecilnya selisih absorbansi antar selang waktu. Absorbansi tersebut didapat saat pengukuran pada panjang gelombang maksimum $1 \mathrm{~mL}$ larutan ABTS 7 mM. Vitamin C digunakan sebagai kontrol positif pada penelitian ini karena merupakan salah satu sumber antioksidan yang mudah diperoleh, banyak dikonsumsi masyarakat, aktivitas antioksidannya tinggi dan sangat kuat (16). Fungsi kontrol positif adalah sebagai pembanding apakah zat uji bisa berefek sama dengan sumber antioksidan standar yang digunakan sebagai kontrol positif. Kurva persamaan regresi linier $\mathrm{y}=\mathrm{bx}+\mathrm{a}$ antara konsentrasi larutan uji $(\mathrm{x})$ dengan persentase aktivitas antioksidan $(\mathrm{y})$ dari air perasan jeruk manis, air perasan jeruk purut, dan vitamin C dapat dilihat pada Gambar 1, Gambar 2, dan Gambar 3.

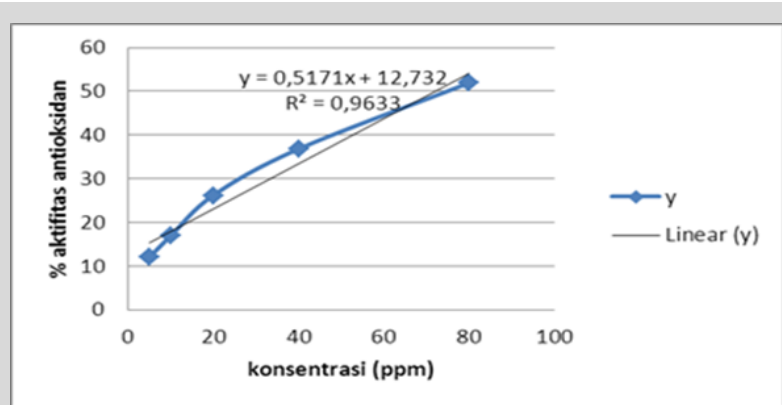

Gambar 1. Kurva persamaan regresi linier aktivitas antioksidan perasan jeruk manis.

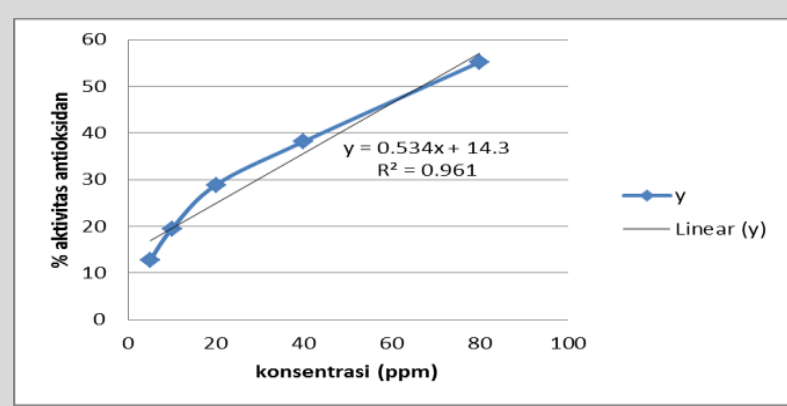

Gambar 2. Kurva persamaan regresi linier aktivitas antioksidan perasan jeruk purut.

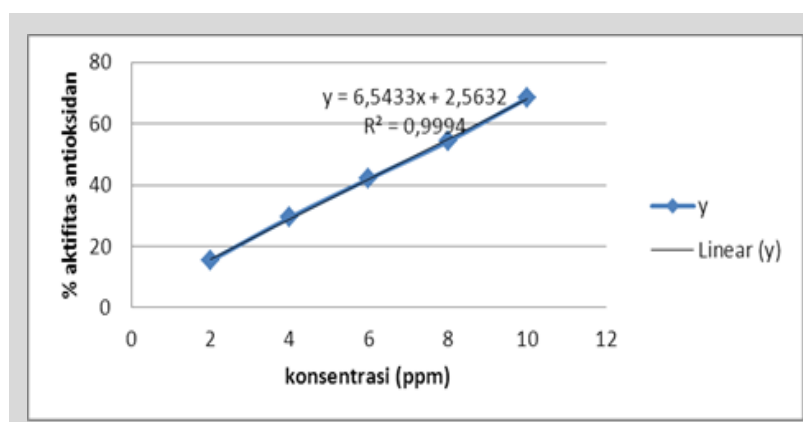

Gambar 3. Kurva persamaan regresi linier aktivitas antioksidan vitamin C.

Kurva persamaan regresi linier digunakan untuk menghitung nilai $\mathrm{IC}_{50}$. Besarnya Aktivitas antioksidan ditunjukkan dengan nilai $\mathrm{IC}_{50}$. Inhibition concentration 50 (IC 50 ) adalah konsentrasi efektif senyawa dalam sampel yang dapat menghambat $50 \%$ absorbansi ABTS. Nilai IC $_{50}$ berbanding terbalik dengan kemampuan senyawa yang bersifat sebagai antioksidan. Semakin kecil nilai $\mathrm{IC}_{50}$ semakin besar kemampuan aktivitas antioksidannya. Perbandingan $\mathrm{IC}_{50}$ antara air perasan jeruk manis, air perasan jeruk purut, dan vitamin C dapat dilihat pada Tabel 1.

\begin{tabular}{|c|c|}
\hline Sampel & $\mathrm{IC}_{50}(\mathrm{ppm})$ \\
\hline Perasan jeruk manis & $71,34 \pm 0,69$ \\
\hline Perasan jeruk purut & $67,92 \pm 1,75$ \\
\hline Vitamin C & $7,25 \pm 0,02$ \\
\hline
\end{tabular}

Air perasan jeruk manis dan jeruk purut mempunyai aktivitas antioksidan yang kuat. Suatu senyawa dikatakan berpotensi sebagai antioksidan kuat jika memiliki nilai IC $\mathrm{C}_{50}$ 50-100 ppm, sedangkan vitamin $\mathrm{C}$ aktivitas antioksidannya dengan $\mathrm{IC}_{50}$ sebesar 7,25 $\pm 0,02 \mathrm{ppm}$, hal ini menunjukkan vitamin $\mathrm{C}$ merupakan senyawa sintetis murni yang poten sebagai antioksidan (17). Kandungan senyawa yang berkontribusi terhadap aktivitas antioksidan pada jeruk manis dan jeruk purut antara lain flavonoid, vitamin C, fenol, saponin, dan tanin (18).

\section{KESIMPULAN}

Perasan jeruk manis dan jeruk purut mengandung senyawa flavonoid dan vitamin C. Perasan jeruk manis memiliki aktivitas antioksidan dengan metode ABTS, dengan nilai IC $_{50}$ $71,34 \pm 0,69$ ppm dan perasan jeruk purut sebesar $67,92 \pm 1,75$ ppm. Perasan jeruk manis dan jeruk purut mempunyai aktivitas antioksidan yang kuat.

\section{DAFTAR PUSTAKA}

1. Touyz, R.M and Schiffrin EL. 2004. Reactive Oxygen Species in Vaskular Biology: Implications in Hypertension. Histochem Cell Biol, 122, 339352.

2. Nishantini, A.A., Ruba, A., and Mohan, V.R. 2012. Total Phenolic, Flavonoid Contents and In Vitro Antioxidant Activity of Leaf of Suaeda monoica Forssk ex. Gmel (Chenopodiaceae). International Journal of Advanced Life Sciences (IJALS), 1, 5:34-43.

3. Widowati, W., Safitri, R., Rumumpuk, R., dan Siahaan, M. 2005. Penapisan Aktivitas Superoksida Dismutase pada Berbagai Tanaman. Universitas Kristen Maranatha Bandung, MKU, Universitas Padjadjaran Bandung, Fakultas MIPA, Universitas Negeri Menado, Fakultas MIPA Universitas Advent Indonesia Bandung, Fakultas MIPA, 5, 1, 33-48.

4. Handayani, R, and Sulistyo, J. 2008. Sintesis Senyawa Flavonoid- $\lambda$ Glikosida secara Reaksi Transglikosilasi Enzimatik dan Aktivitasnya sebagai Antioksidan. Biodiversitas, 9: 1-4

5. Rauf A, Uddin G, Arfan M, Ali J. 2014, Phytochemical analysis and radical scavenging profile of juices of Citrus sinensis, Citrus anrantifolia, and Citrus limonum. Organic and Medical Chemistry Letters, 4:5. 
6. Risnauli S. 2017. Uji Aktivitas Antioksidan Ekstrak Etanol Kulit Buah Jeruk Purut (Citrus hystrix) Dengan Metode Perangkapan DPPH (1,1diphenyl-2-picryhydrazyl). Skripsi,Universitas Sumatera Utara Medan.

7. Teti, A. 2013. Uji Daya Antioksidan Menggunakan Radikal 1,1-difenil-2pikrilhidrazil dan Penetapan Kandungan Fenolik Total Fraksi Etil Asetat Ekstrak Etanol Kulit Jeruk Manis (Citrus sinensis (L.) Osbeck). Skripsi, Fakultas Farmasi Universitas Sanata Dharma Yogyakarta.

8. Warsito, Noorhamdani, Sukardi, Suratmo. 2017. Aktivitas Antioksidan Dan Antimikroba Minyak Jeruk Purut(Citrus hystrix DC.) dan Komponen Utamanya. Journal of Environmental Engineering \& Sustainable Technology, 04, 1: 13-18

9. Apak, R., Guclu, K., Demirata, B., Ozyurek, M., Celik, S.E., Bektasoglu, B., Berker K,I., dan Ozyurt, D. 2007. Comparative Evaluation of Various Total Antioxidant Capacity Assays Applied to Phenolic Compounds With The CUPRAC Assay. Molecules, 12:7, 1496-547.

10. Endarto, O., dan Martini, E. 2016. Pedoman Budi Daya Jeruk Sehat, World Agroforestry Centre (ICRAF), Bogor, 94-95.

11. Solichah, M. 2018. UjiAktivitas Antioksidan Air Perasan Jeruk Nipis (Citrus aurantifolia S.) Dengan Metode ABTS (2,2-Azinobis(3ethylbenzothiazoline)-6-sulfonic acid) Dan Pentapan Kadar Flavonoidnya. Skripsi, Universitas Wahid Hasyim Semarang.
12. Van Steenis, C.G.G.J. 1981. Flora Untuk Sekolah Indonesia. PT. Pradnya Paramita, Jakarta.

13. Harborne, J.B. 1987. Metode Fitokimia, diterjemahkan oleh Kosasih Padmawinata dan Iwan Sudiro. Cetakan Kedua, Institute Teknologi Bandung, Bandung, 69-76

14. Setiabudi, D. A., and Tukiran. 2017. Uji Skrining Ekstrak Metanol Kulit Batang Tumbuhan Klampok Watu (syzygium litorale). UNESA Journal of Chemistry, 6, 3

15. Oliveira, S.D., Souza, G.A., Eckert, C.R., Silva, T.A., Sobral, E.S., Favero, O.A., Ferreira, M.J.P., Romoff, P., and Baader, W.J. 2006. Evaluation of Antiradical Assays Used Indetermining The Antioxidant Capacity of Pure Compounds and Plant Extracts. Quim Nova, 37:3, 497-503.

16. Sandhiutami dan Dwi, N.M. 2010. Uji Aktivitas Antioksidan Minyak Buah Merah (Pandanus conoideus Lam.) Secara In Vitro dan In Vivo pada Tikus yang diberi Beban Aktivitas Fisik Maksimal. Jurnal Sains dan Teknologi Farmasi, 15:1, 1-5.

17. Blois, M.S. 1958. Antioxidant determinations by the use of a stable free radical. Nature, 181, 1199-1200.

18. Risnauli S. 2017. Uji Aktivitas Antioksidan Ekstrak Etanol Kulit Buah Jeruk Purut (Citrus hystrix) Dengan Metode Perangkapan DPPH $(1,1$ diphenyl-2-picryhydrazyl). Skripsi,Universitas Sumatera Utara Medan. 